\title{
Roles of the mammalian target of rapamycin (mTOR) signaling pathway in the repair of hyperoxia-induced acute lung injury
}

\author{
Shao-Hua Wang ${ }^{A, C, D, F}$, Long-Hui Li ${ }^{A, D, F}$, Dong-Mei Zou ${ }^{B, E, F}$, Xue-Mei Zheng ${ }^{B, E, F}$, Jian Deng ${ }^{C, E, F}$ \\ Neonatal Intensive Care Unit, Women and Children Health Institute Futian, University of South China, Shenzhen, China \\ A - research concept and design; $B$ - collection and/or assembly of data; C - data analysis and interpretation; \\ $D$ - writing the article; $E$ - critical revision of the article; $F$ - final approval of the article
}

Address for correspondence

Shao-Hua Wang

E-mail:wangshua2017@163.com

\section{Funding sources}

This study was supported by the Science and Technology Committee, Shenzhen, China (45576779-3) and the Health and Family Planning Committee, Shenzhen, China (201505022).

\section{Conflict of interest}

None declared

Received on March 21, 2017

Reviewed on May 27, 2017

Accepted on July 31, 2017

Published online on November 26, 2019

Cite as

Wang SH, Li L-H, Zou DM, Zheng XM, Deng J. Roles of the mammalian target of rapamycin (mTOR) signaling pathway in the repair of hyperoxia-induced acute lung injury. Adv Clin Exp Med. 2020;29(1):13-23. doi:10.17219/acem/76170

DOI

10.17219/acem/76170

\section{Copyright}

Copyright by Author(s)

This is an article distributed under the terms of the

Creative Commons Attribution Non-Commercial License

(http://creativecommons.org/licenses/by-nc-nd/4.0/)

\begin{abstract}
Background. Rapamycin inhibits the mammalian target of rapamycin (mTOR) activity and has been proven effective for the treatment of lung injury.
\end{abstract}

Objectives. The objective of this study was to investigate the roles of the mTOR pathway and its inhibitor rapamycin in the repair of hyperoxia-induced acute lung injury (ALI).

Material and methods. Firstly, premature rat lung fibroblast L929 cells were cultured under different oxygen concentrations (40\%, 60\% and 90\%). At day 3,7 and 14 after exposure, MTT assay and flow cytometry were used to evaluate the effect of oxygen stress on cell viability and apoptosis of L929 cells, respectively. Secondly, microscopy, MTT assay and flow cytometry was used to investigate the effect of $10 \mathrm{nM}$ rapamycin on $90 \% \mathrm{O}_{2}$ exposed L929 cells. We also used small interfering RNAs (siRNAs) to abrogate the expression of mTOR in $90 \% \mathrm{O}_{2}$ exposed $\mathrm{L} 929$ cells, and then evaluated the apoptosis and cell viability using flow cytometry and the MTT assay, respectively. In addition, western blot was used to detect the protein expression of BCl-2, p53, TGF- $\beta$ and connective tissue growth factor (CTGF). A hyperoxia-induced lung injury model was established in Sprague Dawley (SD) rats in order to evaluate the histopathological changes in lung tissues and expression of the mTOR pathway and fibrosis related factors.

Results. Exposure to $40 \%, 60 \%$ or $90 \%$ oxygen all significantly inhibited the growth of L929 cells. Application of $10 \mathrm{nM}$ rapamycin was found to effectively promote apoptosis of $90 \% \mathrm{O}_{2}$ exposed L929 cells. In addition, mTOR siRNA promoted the apoptosis and inhibited the growth of L 929 cells. Rapamycin inhibited the activation of the mTOR signaling pathway, down-regulated the expression of downstream proteins p70S6K and 4EBP1, reduced the collagen deposition and the production of fibrosis-inducing factors, including TGF- $\beta$ and CTGF in hyperoxia-induced lung injury rats.

Conclusions. Rapamycin may be useful for the treatment of hyperoxia-induced acute lung injury (ALI) by inhibiting the activation of mTOR signaling pathway.

Key words: mTOR, rapamycin, siRNA interference, hyperoxia-induced lung injury 


\section{Introduction}

Bronchopulmonary dysplasia (BPD), a form of chronic lung disease (CLD), is characterized by the abnormal formation of alveoli and chronic pulmonary vascular changes, especially in preterm infants. ${ }^{1}$ BPD has a reported incidence of $>60 \%$ in preterm infants, and is one of the leading causes of death and disability in preterm infants in China. ${ }^{2}$ Oxygen therapy is a common method for the treatment of preterm infants, and appropriate oxygen therapy can effectively save the lives of preterm infants suffering from hypoxia. ${ }^{3}$ However, sustained oxygen inhalation at high concentrations can lead to extensive and non-specific inflammatory responses in lung tissue, followed by pulmonary stromal hyperplasia, and pulmonary fibrosis, or even acute lung injury (ALI). ${ }^{4}$ Lung fibroblasts (LFs) are the main cells involved in the repair of lung injury. ${ }^{5}$ The accumulation of the abnormal extracellular matrix (ECM) that is produced by LFs plays an important role in the pathogenesis of BPD fibrosis. ${ }^{6}$ Currently, one of the major problems in the prevention and early treatment of lung injury is the excessive proliferation of LFs in lung repair and reconstruction, which may end up replacing the normal terminal bronchioles and alveoli, resulting in irreversible damage of both the structure and function of the lung. ${ }^{7,8}$

As a serine/threonine protein kinase, mammalian target of rapamycin (mTOR) is a member of the phosphoinositide3-kinase-related kinase family (PI3K). The mTOR signaling pathway can phosphorylate multiple target proteins for the regulation of transcription, translation initiation, protein synthesis, and degradation, mainly through the activation of p70S6K/S6 and the inhibition of 4EBPI/eIF4E. ${ }^{9-11}$ Mammalian target of rapamycin signaling pathway has been shown to be able to regulate embryonic development, ${ }^{12,13}$ and lung development ${ }^{14}$, and is involved in a variety of lung diseases, such as chronic obstructive pulmonary disease (COPD), ${ }^{15}$ cystic fibrosis, ${ }^{16}$ and pulmonary fibrosis. ${ }^{17}$

Pulmonary fibrosis is characterized by the activation of the mTOR and its down-stream target, the ribosomal S6 kinase (p70S6K), pulmonary fibrosis generated fibrotic foci with abundant activated hepatic stellate cells and excessive collagen deposition, it has been reported that rapamycin, an inhibitor of p70S6K phosphorylation, could inhibit hepatic stellate cell proliferation and limits fibrogenesis. ${ }^{18-20}$ Blocking the mTOR signaling pathway has been shown to suppress the proliferation of fibroblasts and the over-production of extracellular matrix (ECM) in liver tissue, which may reverse pulmonary fibrosis. ${ }^{20}$ Rapamycin is a macrolide immunosuppressive agent, an inhibitor of mTOR, and it has been proven effective for the treatment of pulmonary fibrosis. ${ }^{21}$ Nevertheless, the detailed molecular mechanisms underlying the role of the mTOR signaling pathway in the repair of hyperoxia-induced lung injury have not yet been fully elucidated and require further investigation.
In this study, we aim to investigate the roles of mTOR signaling pathway in the repair of hyperoxia-induced acute lung injury in vivo and in vitro.

\section{Material and methods}

\section{Ethics statement}

All animal handling procedures were carried out in accordance with the protocols approved by the Institutional Animal Care and Use Committee of University of South China (No. 2014). ${ }^{11}$

\section{Animals and cell lines}

The mouse lung fibroblast cell line L929 was purchased from the American Type Culture Collection (ATCC) (Manassas, USA). The L929 cells were thawed at $37^{\circ} \mathrm{C}$, centrifuged at $1000 \mathrm{~g}$ for $5 \mathrm{~min}$, and rinsed twice with RPMI-1640 medium containing 10\% fetal bovine serum (Gibco, USA). Cells were harvested by centrifugation at $1000 \mathrm{~g}$ for $5 \mathrm{~min}$, and cultured in RPMI-1640 medium containing 10\% fetal bovine serum (Gibco, USA), which was replaced every day. Fifty-four specific-pathogen-free (SPF) SD rats (weighing 225-240 g and aged 8 weeks), including 36 females and 18 males, were obtained from the Experimental Animal Center of Nanhua University (Hunan, China). Female and male rats were co-housed at a ratio of 2:1 for mating. Females were checked for the identification of vaginal plugs each morning. The day a vaginal plug was identified was the $1^{\text {st }}$ day of pregnancy. On the $21^{\text {st }}$ day of pregnancy, 66 neonatal rats were obtained as the premature rats in this study. These 66 premature rats were used for 2 parts of the in vivo studies. In the first part of animal study, 42 premature rats were included and divided into 7 groups ( $\mathrm{n}=6 \mathrm{per}$ group): 1) control, 2) $90 \% \mathrm{O}_{2} 3 \mathrm{~d}$, 3) $90 \% \mathrm{O}_{2} 7 \mathrm{~d}$, 4) $90 \% \mathrm{O}_{2} 14 \mathrm{~d}$, 5) $90 \% \mathrm{O}_{2}+$ rapamycin $3 \mathrm{~d}$, 6) $90 \% \mathrm{O}_{2}+$ rapamycin $7 \mathrm{~d}$, 7) $90 \% \mathrm{O}_{2}+$ rapamycin $14 \mathrm{~d}$. In the second part of animal study, 24 premature rats were included and divided into 4 groups ( $\mathrm{n}=6$ per group): 1 ) $\left.90 \% \mathrm{O}_{2}, 2\right) 90 \% \mathrm{O}_{2}+$ rapamycin 3d, 3) $90 \% \mathrm{O}_{2}+$ rapamycin $7 \mathrm{~d}$, 4) $90 \% \mathrm{O}_{2}+$ rapamycin $14 \mathrm{~d}$.

\section{Oxygen exposure on L929 cells}

L929 cells were cultured in $37^{\circ} \mathrm{C}$ with $5 \%$ of carbon dioxide and in saturated humidity until moisture began adhering to the wall. After aspiration of the culture medium, the cells were rinsed twice with $37^{\circ} \mathrm{C}$ pre-warmed $\mathrm{PBS}$, and cultured in fresh complete medium. The L929 cells were cultured in distinct media and were randomly divided into 4 groups (control, $40 \% \mathrm{O}_{2}, 60 \% \mathrm{O}_{2}$, and $90 \% \mathrm{O}_{2}$ ). The control group cells were cultured in fresh complete medium with regular air at $37^{\circ} \mathrm{C}$. The other 3 groups were cultured in fresh complete medium under different oxygen concentrations $(40 \%, 60 \%$ and $90 \%)$ in independent culture 
chambers. Air, including the specific concentrations of oxygen and nitrogen, as well as $5 \% \mathrm{CO}_{2}$, was injected into the culture chamber at a speed of $1 \mathrm{~L} / \mathrm{min}$ for $30 \mathrm{~min}$. The culture chamber was sealed once the oxygen monitor showed expected oxygen concentrations, and placed in an incubator for culture. The $40 \%$ oxygen group was cultured in $40 \% \mathrm{O}_{2}, 55 \% \mathrm{~N}_{2}$ and $5 \% \mathrm{CO}_{2}$. The $60 \%$ oxygen group was cultured in $60 \% \mathrm{O}_{2}, 35 \% \mathrm{~N}_{2}$ and $5 \% \mathrm{CO}_{2}$. The $90 \%$ oxygen group was cultured in $90 \% \mathrm{O}_{2}, 5 \% \mathrm{~N}_{2}$ and $5 \% \mathrm{CO}_{2}$. The corresponding concentration air was injected to the culture chambers every $12 \mathrm{~h}$ to confirm that the oxygen concentration was as expected. After being cultured for 3,7 , or 14 days, the cells of each group were harvested for follow-up experiments.

\section{Rapamycin intervention}

The $90 \%$ oxygen group of L929 cells was cultured in $37^{\circ} \mathrm{C}$ with $5 \%$ carbon dioxide and saturated humidity (until moisture adhered to the wall). After aspiration of the culture medium, the cells were rinsed twice with $37^{\circ} \mathrm{C}$ pre-warmed PBS, and were then cultured in fresh complete medium with $10 \mathrm{nM}$ rapamycin in independent culture chambers. In order to keep the oxygen concentration in the culture consistent, mixed air of the specific oxygen and nitrogen concentrations, and $5 \% \mathrm{CO}_{2}$, was injected into the culture chambers every $12 \mathrm{~h}$. After being cultured for 3 days under $90 \%$ concentration of oxygen concentration, the cells were harvested for follow-up experiments.

\section{Flow cytometry for apoptosis}

To evaluate the apoptosis of L929 cells, cells were double stained with annexin V-FITC and PI, and analyzed by flow cytometry (BD Biosciences, New York, USA). The L929 cells $\left(10^{5} / \mathrm{mL}\right)$ cultured under different conditions were incubated at $37^{\circ} \mathrm{C}$ and $5 \% \mathrm{CO}_{2}$ for $24 \mathrm{~h}$ before being digested by trypsin without EDTA. The cells were then rinsed with pre-cooled PBS, centrifuged at $1500 \mathrm{~g}$ for $5 \mathrm{~min}$, and resuspended in $300 \mu \mathrm{L}$ of $\times 1$ binding buffer. After incubation with Annexin V-FITC $(5 \mu \mathrm{L})$ for $15 \mathrm{~min}$ and PI $(10 \mu \mathrm{L})$ for 5 min, the L929 cells were analyzed by FACSCalibur flow cytometry (BD Biosciences).

\section{MTT assay for cell viability}

To evaluate the cell viability of L929 cells, the cell concentration of each group was adjusted to $3 \times 10^{4}$ cells $/ \mathrm{mL}$. The L929 cells were inoculated into a 96-well culture plate and $15 \mu \mathrm{L}$ MTT was added to each well. Cells were incubated at $37^{\circ} \mathrm{C}$ in a humidified chamber and $5 \% \mathrm{CO}_{2}$ for $3-4 \mathrm{~h}$. After aspiration, $200 \mu \mathrm{L}$ DMSO was added to each well and incubated at room temperature in a shaker for $10 \mathrm{~min}$; the absorbance of each well was measured at $492 \mathrm{~nm}$. All samples were assayed in duplicate.

\section{Inverted phase contrast microscopy}

L929 cells exposed to $90 \% \mathrm{O}_{2}$ concentrations of oxygen, with rapamycin intervention, were harvested after 3 days. The morphology and number of L929 cells were evaluated under an inverted phase contrast microscope to investigate the effects of rapamycin on the morphology of oxygen exposed L929 cells.

\section{Inhibition of mTOR expression using siRNA}

The cells were diluted to a concentration of $1 \times 10^{5} \mathrm{cells} / \mathrm{mL}$ and inoculated in a 6 -well plate $(3 \mathrm{~mL} /$ well). They were then cultured at $37^{\circ} \mathrm{C}$ and $5 \% \mathrm{CO}_{2}$ for $24 \mathrm{~h}$. To prepare siRNA-Lipofectamine for (Invitrogen, Carlsbad, USA) L929 cell transfection, 75 pmol synthesized mTOR siRNA diluted in $100 \mu \mathrm{L}$ serum-free RPMI1640 medium (Invitrogen Life Technologies, New York, USA), and $5 \mu \mathrm{L}$ lipofectamine 2000 diluted in $100 \mu \mathrm{L}$ serum-free RPMI1640 medium were mixed and incubated at room temperature for $20 \mathrm{~min}$. After cells were washed with PBS, $200 \mu \mathrm{L}$ siRNA-Lipofectamine 2000 was added to each well and cells were incubated at $37^{\circ} \mathrm{C}$ and $5 \% \mathrm{CO}_{2}$ for $4-6 \mathrm{~h}$. The supernatant was removed and $3 \mathrm{~mL}$ RPMI1640 was added to each well. The siRNA-transfected L929 cells were divided into 4 groups: control, $90 \% \mathrm{O}_{2}, 90 \% \mathrm{O}_{2}+$ rapamycin $(10 \mathrm{nM})$, and the mTOR siRNA groups.

\section{Quantitative real-time PCR}

The mTOR siRNA transfected cells were harvested for RNA isolation using the Trizol reagent (Takara, Japan). The Takara kits were used for cDNA synthesis and qPCR, which was conducted in a $20 \mu \mathrm{L}$ reaction system with $10 \mu \mathrm{L}$ $2 \times$ Mix buffer (Aidlab Biotechnologies, Beijing, China), forward and reverse primers (Table 1) $(0.4 \mu \mathrm{L}$ each), $1 \mu \mathrm{L}$ DNA, and 15.4 $\mu \mathrm{L}$ double distilled water. The primers used in this study were shown in Table 1 . The qPCR was conducted according to the following program: $94^{\circ} \mathrm{C}$ for $5 \mathrm{~min}$, 25 cycles of denaturation at $94^{\circ} \mathrm{C}$ for $1 \mathrm{~min}$, annealing at $55^{\circ} \mathrm{C}$ for $1 \mathrm{~min}$, and extension at $72^{\circ} \mathrm{C}$ for $40 \mathrm{~s}$. Glyceraldehyde 3-phosphate dehydrogenase (GAPDH) was used as the internal reference. The relative mRNA level was

Table 1. The primers for real-time quantitative PCR

\begin{tabular}{|c|c|}
\hline Gene names & Primers sequences $\left(5^{\prime}-3^{\prime}\right)$ \\
\hline \multirow{2}{*}{ GAPDH } & F: CCGAGAATGGGAAGCTTGTC \\
\hline & R: AAGCACCAACAGAGGAGAA \\
\hline \multirow{2}{*}{ mTORC1 } & F: TCAACTGGGGAAGAAGTACC \\
\hline & R:TCATGGGTCCTGTCTCAACT \\
\hline \multirow{2}{*}{ p70s6K } & F: AAATCTCCATGGCTTTGGGG \\
\hline & R: AGGGGCCATGTATTCTATTG \\
\hline \multirow{2}{*}{$4 E B P 1$} & F: CCAGGATTATCTATGACCGG \\
\hline & R: AATTGTGACTCTTCACCGCC \\
\hline
\end{tabular}


calculated according to the $2^{-\Delta \Delta C t}$ method with ABI Prism 7500 SDS software (Applied Biosystems, Foster City, USA).

\section{Western blot}

Harvested cells were mixed with $500 \mu \mathrm{L}$ RIPA lysate with PMSF (Sigma-Aldrich, St. Louis, USA) and incubated on ice for $2 \mathrm{~h}$, before being centrifuged at $12,000 \mathrm{~g}$ at $4^{\circ} \mathrm{C}$ for $10 \mathrm{~min}$ to obtain the supernatant. Protein quantification was performed using the BCA method. Western blotting was used to evaluate the protein expressions of $\mathrm{p} 70 \mathrm{~S} 6 \mathrm{~K}$ and 4EBP1 proteins in the control and mTOR siRNA groups. The expressions of $\mathrm{Bcl}-2$, p53, TGF- $\beta$, and connective tissue growth factor (CTGF) in the control, $90 \% \mathrm{O}_{2}, 90 \% \mathrm{O}_{2}+$ rapamycin, and mTOR siRNA groups were also evaluated using western blot. Relative density of western blot band was analyzed by using Image J software (National Institutes of Health, Bethesda, USA; http://imagej.nih.gov/ij/) and protein expression level of each group was normalized with $\beta$-actin.

\section{Establishment of a model of hyperoxia-induced lung injury in SD rats and rapamycin intervention}

On the $21^{\text {st }}$ day of pregnancy, the rats were sacrificed in order to obtain premature neonatal rats. After 3, 7, and 14 days, the premature rats were sacrificed for follow-up experiments ( $\mathrm{n}=6$ rats per group). The hyperoxia-induced lung injury rat model was established according to the study conducted by Zhang, et al. ${ }^{22}$ Briefly, the premature rats were raised in $90 \%$ oxygen $(5-6 \mathrm{~L} / \mathrm{min})$, at $22-25^{\circ} \mathrm{C}$, and $65-75 \%$ humidity with unlimited food and water. The $\mathrm{CO}_{2}$ level in the rat house was set to $5 \%$, using the appropriate amount of barium hydroxide. Sun et al. ${ }^{23}$ reported that mTOR signaling was blocked by intraperitoneal injection of rapamycin $(1.5 \mathrm{mg} / \mathrm{kg})$ in mice, thus $1.5 \mathrm{mg} / \mathrm{kg}$ dose of rapamycin was chosen in the animal study. Next, the $90 \% \mathrm{O}_{2}+$ rapamycin group received intraperitoneal injection of rapamycin $(1.5 \mathrm{mg} / \mathrm{kg})$ once a day. To avoid hyperoxicosis, the maternal rats of the control and hyperoxia groups were interchanged every $24 \mathrm{~h}$.

\section{Histopathological examination}

Six rats were randomly selected from each group and sacrificed for lung dissection. The left lung was fixed in $4 \%$ paraformaldehyde to prepare paraffin sections for histopathological examination. The paraffin sections were stained with hematoxylin and eosin and examined under light microscopy (XDS-1A; Supore, Shanghai, China). Other lung tissue was washed with $\mathrm{PBS}$ at $4^{\circ} \mathrm{C}$ for $3 \mathrm{~min}$ and frozen in liquid nitrogen for follow-up experiments. In order to evaluate the effects of $90 \%$ oxygen and intraperitoneal injection of $1.5 \mathrm{mg} / \mathrm{kg}$ rapamycin on lung tissues of rats, histopathological scores were evaluated according to the protocol developed by Murakami et al. ${ }^{24}$

\section{Enzyme-linked immunosorbent assay}

Five lung tissue samples (10 mg per sample) randomly selected from each group were homogenized in cold PBS $(\mathrm{pH}=7.4)$. The homogenate was centrifuged at $10,000 \mathrm{~g}$ for $20 \mathrm{~min}$ at $4^{\circ} \mathrm{C}$. Total protein concentration of each sample was assayed using a BCA protein quantification kit (Sangon, Shanghai, China). The contents of collagen I, collagen III, and FN in ECM were measured using an ELISA kit (Cosmo Bio, Tokyo, Japan) according to the manufacturer's instructions. The absorbance was measured at $450 \mathrm{~nm}$ on a microtiter reader (Thermo Fisher Scientific, Waltham, USA). In addition, the levels (ng/mg) of TGF- $\beta$, CTGF, and collagen I in the lung tissue of premature rats were also determined with an ELISA kit (Sangon, Shanghai, China) according to the manufacturer's instructions. Absorbance values were normalized to the standard curve.

\section{Western blot analysis for the expression of $\mathrm{mTORC1}$, p70S6K, and 4EBP1 in lung tissues}

The lung tissue was washed with pre-cooled saline to remove residual blood and was then dried. One gram of lung tissue was used to prepare a $10 \%$ lung homogenate. After centrifugation at a low temperature, the supernatant from the lung homogenate was used for western blot to quantity the protein levels of mTORC1, p70S6K, and 4EBP1.

\section{Statistical analyses}

The data was expressed as mean \pm standard deviation $(\mathrm{x} \pm \mathrm{SD})$ and analyzed using SPSS V. 19.0 software (IMB Corp., Armonk, USA). One way analysis of variance (ANOVA) for repeated measures and post-hoc Tukey's test for pairwise comparison were performed. A p-value less than 0.05 was considered to be statistically significant.

\section{Results}

Oxygen exposure induced apoptosis and inhibited proliferation in L929 cells in a time and concentrationdependent manner.

The L929 cells exposed to $40 \%, 60 \%$ and $90 \%$ oxygen exhibited significantly higher apoptosis rates than those cultured in regular air for the same time period $(3,7$, or 14 days) in a time and concentration-dependent manner ( $\mathrm{p}<0.05$ ) (Fig. 1A-B). The L929 cells exposed to 40\%, $60 \%$, and $90 \%$ oxygen also exhibited significantly lower cell viability than those cultured in regular air for the same time period $(3,7$, or 14 days) in a time and concentrationdependent manner $(\mathrm{p}<0.05)$ (Fig. 1C). These results suggest that exposure to $40 \%, 60 \%$ and $90 \%$ oxygen all could induced apoptosis and inhibited cell viability of L929 cells in a time and concentration-dependent manner. 
A
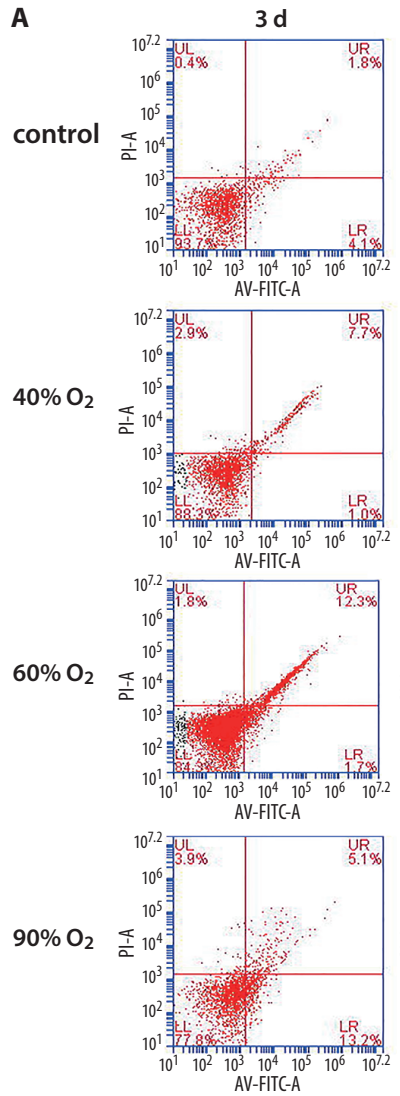
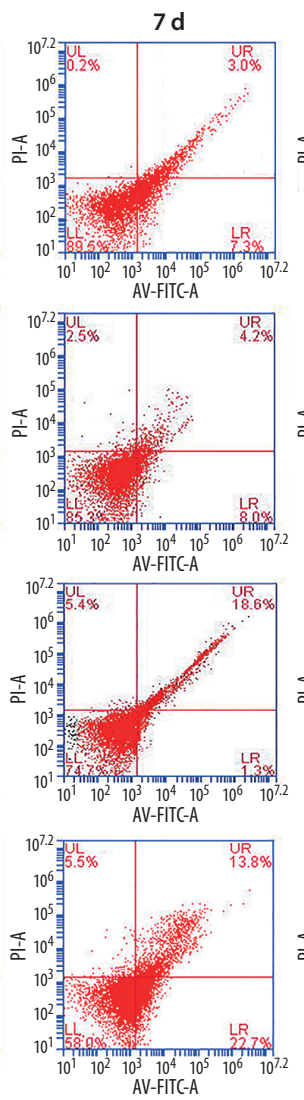
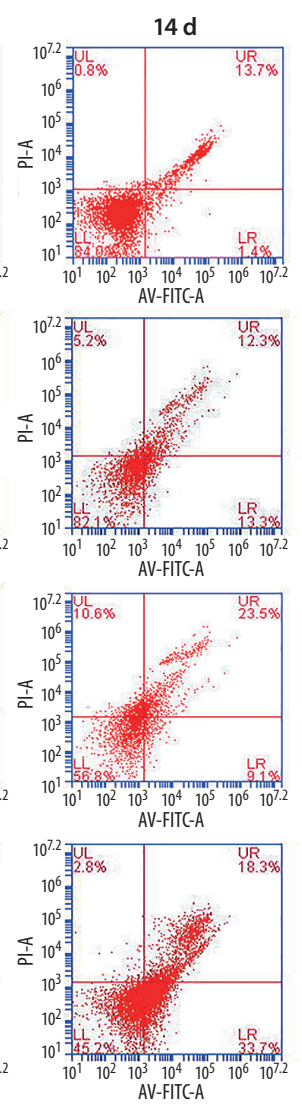

B

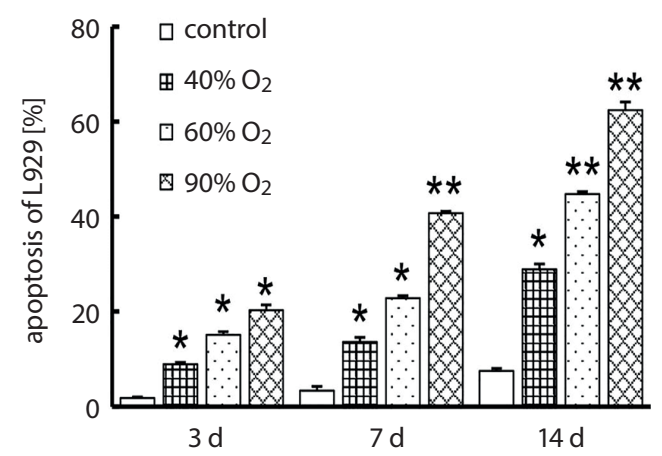

C

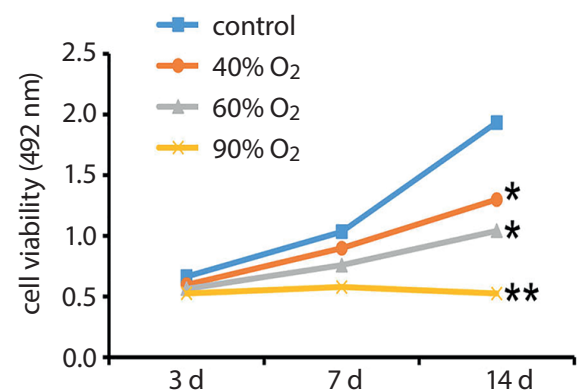

Fig. 1. A,B - flow cytometry analysis for apoptosis of L929 cells exposed to $40 \%, 60 \%$ and $90 \%$ of oxygen; C - MTT assay for cell viability of L929 cells exposed to $40 \%, 60 \%$ and $90 \%$ of oxygen

${ }^{*} p<0.05 ;{ }^{* *} p<0.01$ vs control group.

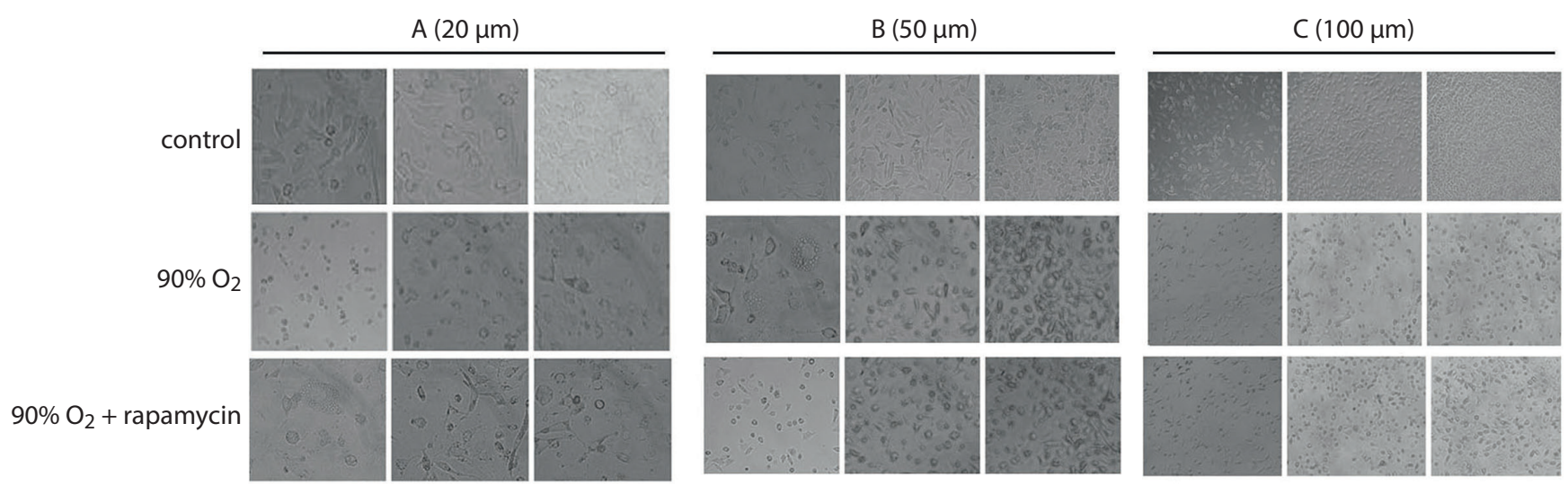

Fig. 2. Inverted phase contrast microscopy. L929 cells exposed to $90 \% \mathrm{O}_{2}$ with $10 \mathrm{nM}$ rapamycin intervention were harvested after 3 days. The morphology and number of cells were evaluated under an inverted phase contrast microscope

\section{Effects of $10 \mathrm{nM}$ rapamycin on morphology of $\mathrm{L} 929$ cells exposed to $90 \% \mathrm{O}_{2}$}

According to the results of above, $90 \%$ oxygen caused more severe damage to the L929 cells than 40\% and 60\% oxygen. Therefore, $90 \%$ oxygen was used in the follow-up experiments. We added $10 \mathrm{nM}$ rapamycin to L929 cells exposed to $90 \% \mathrm{O}_{2}$ and cultured for 3 days, to investigate the effects of rapamycin on the morphology of L929 cells. As shown in Fig. 2, the majority of L929 cells cultured with regular air grew well and had bright, translucent, and compact cell bodies. With exposed to $90 \% \mathrm{O}_{2}$, cells cultured with rapamycin exhibited a reduced refractive index and had increased numbers of granules in the cytoplasm, while most cells were still viable and they exhibited a slightly different morphology (Fig. 2).

Rapamycin inhibited the growth and promoted apoptosis of L929 cells exposed to $90 \% \mathrm{O}_{2}$.

The L929 cells cultured with $10 \mathrm{nM}$ rapamycin and exposed to $90 \% \mathrm{O}_{2}$ exhibited significantly higher apoptosis 
A

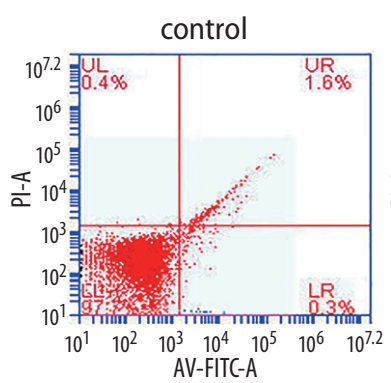

B

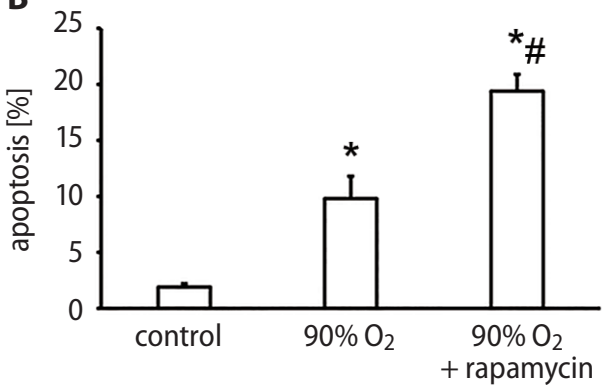

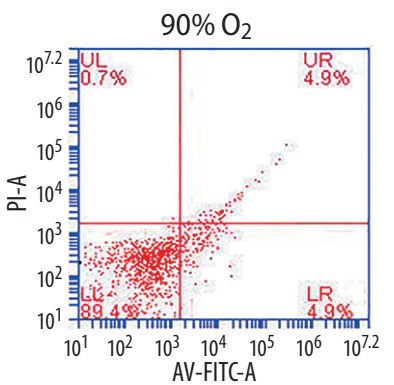

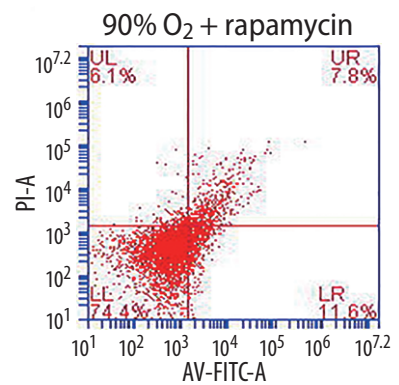

C

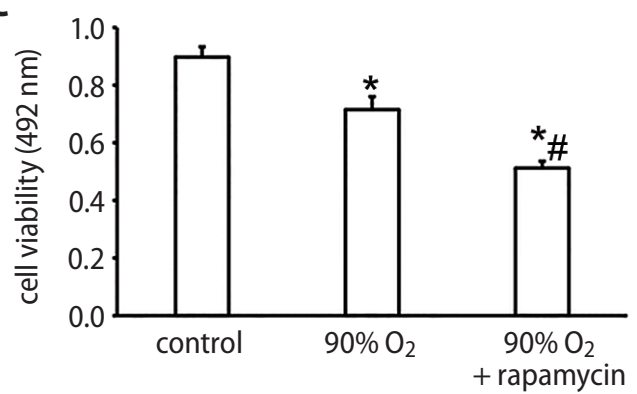

Fig. 3. A,B - Flow cytometry analysis for apoptosis of L929 cells exposed to $90 \% \mathrm{O}_{2}$ with rapamycin intervention; C - MTT assay for cell viability of $\mathrm{L} 929$ cells $90 \% \mathrm{O}_{2}$ with rapamycin intervention

$* p<0.05$ vs control group $\# \mathrm{p}<0.05$ vs $90 \% \mathrm{O}_{2}$ group.
A

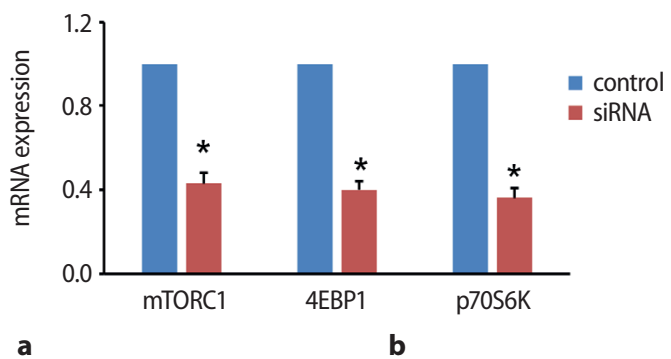

B a

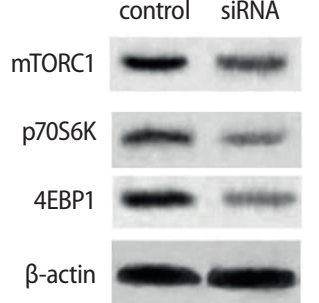

C
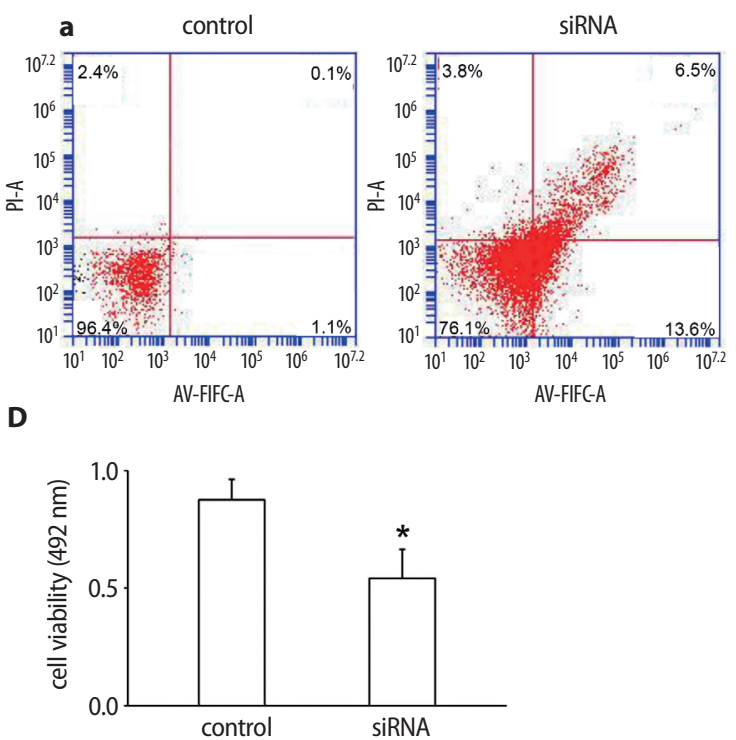

Fig. 4. A - $\mathrm{qPCR}$ analysis for the $\mathrm{mRNA}$ expression of MTORC1, 4EBP1 and p70S6K in L929 cells transfected with mTOR siRNA; B - western blot analysis for the protein expressions of mTORC1, 4EBP1 and p70S6K in L929 cells transfected with mTOR siRNA; C - flow cytometry analysis for the apoptosis of L929 cells transfected with mTOR siRNA; D - MTT assay for cell viability of L929 cells transfected with mTOR siRNA

${ }^{*} p<0.05,{ }^{* *} p<0.01$ vs control group.

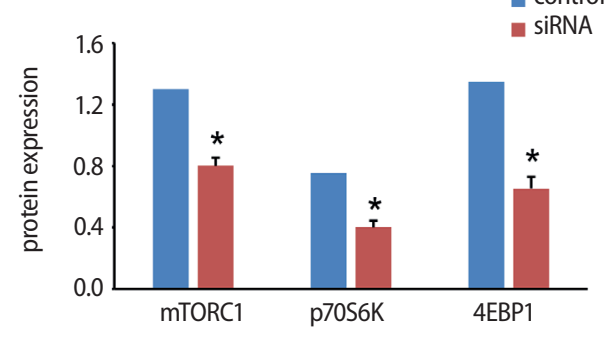

b

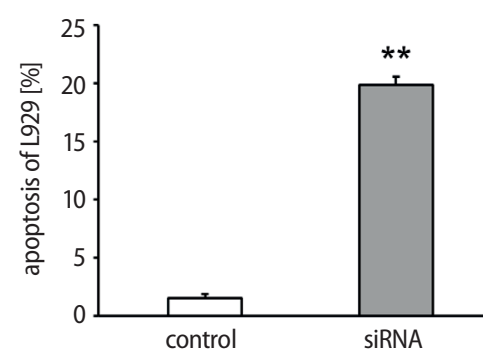


rates than the control group ("p $<0.05$, Fig. 3A,B), and $90 \% \mathrm{O}_{2}$ exposure significantly inhibited the cell viability of L929 cells ("p $<0.05$, Fig. 3C). In addition, the apoptosis ratio was increased and the cell viability was inhibited in the $90 \% \mathrm{O}_{2}+$ rapamycin group compared with $90 \% \mathrm{O}_{2}$ group $(\# \mathrm{p}<0.05)$ (Fig. 3A-C).

\section{Validation of mTOR siRNA}

After transfected with mTOR siRNA in L929 cells, we found that the mRNA and protein expression levels of mTORC1, 4EBP1 and p70S6K in L929 cells transfected with $\mathrm{mTOR}$ siRNA were significantly lower than in control cells ("p $<0.05$, Fig. $4 \mathrm{~A}, \mathrm{~B}$ ). In addition, the rates of apoptotic cells transfected with mTOR siRNA (1.2\%) were significantly increased than in the control $(20.1 \%)(* * \mathrm{p}<0.01$, Fig. 4C), and the cell viability of cells transfected with mTOR siRNA was significantly decreased compared with control group ("p < 0.05, Fig. 4D). These results suggest that mTOR siRNA could down-regulate the expression of mTORC1, 4EBP1 and p70S6K, inhibit the cell viability and promote apoptosis of L929 cells.

\section{Effects of rapamycin and mTOR siRNA on the protein expressions of $\mathrm{BCl}-2, \mathrm{p} 53$, TGF- $\beta$, and CTGF in L929 cells}

We evaluated the protein expressions of apoptosis-related genes, including $\mathrm{p} 53$ and $\mathrm{Bcl}-2$, as well as fibrosis-related genes, including TGF- $\beta$ and CTGF, in L929 cells which were transfected with mTOR siRNA, treated with $10 \mathrm{nM}$ rapamycin, and exposed to $90 \% \mathrm{O}_{2}$. As shown in Fig. 5, the expression of Bcl-2 in cells exposed to $90 \%$ oxygen and cultured with $10 \mathrm{nM}$ rapamycin or transfected with mTOR siRNA was significantly lower than in cells exposed to regular air ("p < 0.05), and mTOR siRNA significantly increased the expression of Bcl-2 compared with $90 \% \mathrm{O}_{2}$ group (\#p < 0.05). The expression level of p53 in L929 cells exposed to $90 \%$ oxygen and cultured with rapamycin or

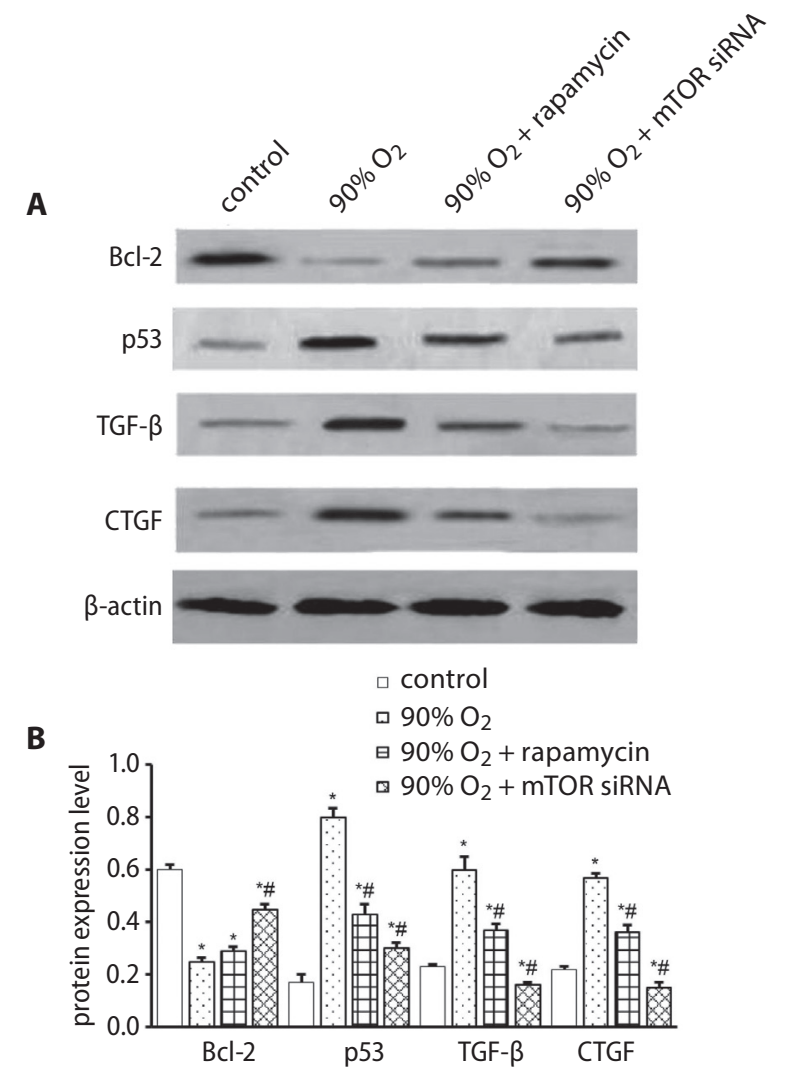

Fig. 5. A - western blot analysis of the protein expressions of $\mathrm{BCl}-2, \mathrm{p} 53$, TGF- $\beta$, and CTGF in the control, $90 \% \mathrm{O}_{2}, 90 \% \mathrm{O}_{2}+$ rapamycin, and $90 \%$ $\mathrm{O}_{2}+$ mTOR-siRNA L929 cell groups; B - relative density of western blot bands was analyzed using ImageJ software

* $\mathrm{p}<0.05$ vs control group; $\# \mathrm{p}<0.05$ vs $90 \% \mathrm{O}_{2}$ group.

those transfected with mTOR siRNA was significantly higher than in cells exposed to regular air ("p $<0.05$ ); however, the application of rapamycin or mTOR siRNA groups all exhibited lower expression level of p53 compared with $90 \% \mathrm{O}_{2}$ group ( $\left.\# \mathrm{p}<0.05\right)$. The expression levels of TGF- $\beta$ and CTGF in L929 cells exposed to $90 \%$ oxygen was significantly higher than in the control group ("p $<0.05)$; however, the application of $10 \mathrm{nM}$ rapamycin or mTOR siRNA groups
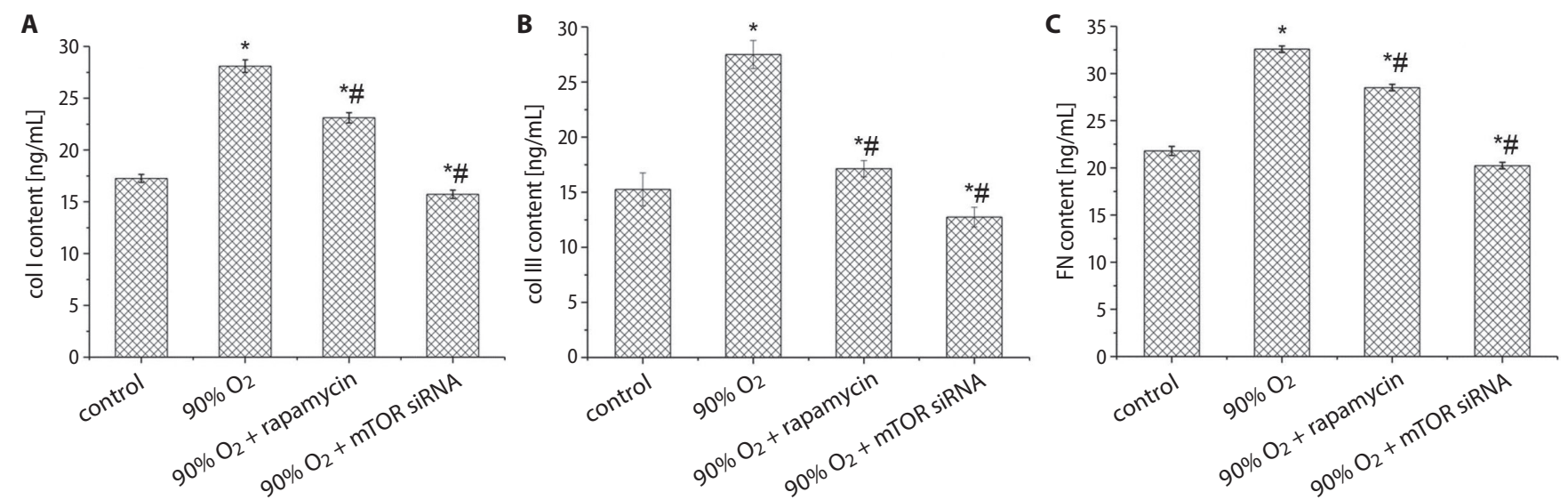

Fig. 6. The contents of col I (A), col III (B) and FN (C) in ECM of L929 cells from each group were determined with ELISA 
all exhibited lower expression levels of TGF- $\beta$ and CTGF compared with $90 \% \mathrm{O}_{2}$ groups. These results suggest that $90 \% \mathrm{O}_{2}$ exposure could promote L929 cell apoptosis and successfully inhibit the expression of CTGF and TGF- $\beta$.

\section{The contents of collagen I, III and fibronectin in extracellular matrix}

The contents of collagen I, collagen III (col I, col III), and fibronectin in extracellular matrix (ECM) of L929 cells exposed to $90 \% \mathrm{O}_{2}$ was significantly higher than those in cells exposed to regular air ("p $<0.05$ ), suggesting that $90 \% \mathrm{O}_{2}$ could induce the production of FN and collagen. However, the contents of col I, col III, and FN in L929 cells treated with rapamycin or transfected with mTOR siRNA were significantly lower than that in $90 \% \mathrm{O}_{2}(\# \mathrm{p}<0.05)$, suggesting that blocking the mTOR signaling pathway suppressed collagen deposition and decreased the production of FN (Fig. 6).

\section{Histopathological changes in the lung tissues}

The lung tissues of control group rats exhibited normal histopathology, without exudation of inflammatory cells

Table 2. The pathological scores of lung injury in rat model $(n=6)$

\begin{tabular}{|l|c|}
\multicolumn{1}{|c|}{ Group } & Pathological scores \\
\hline Control & $1.95 \pm 0.34$ \\
\hline $90 \% \mathrm{O}_{2} 3 \mathrm{~d}$ & $6.33 \pm 2.34^{\mathrm{a}}$ \\
\hline $90 \% \mathrm{O}_{2}+$ rapamycin 3d & $3.50 \pm 0.84^{\mathrm{a}, \mathrm{b}}$ \\
\hline $90 \% \mathrm{O}_{2} 7 \mathrm{~d}$ & $14.0 \pm 2.45^{\mathrm{a}}$ \\
\hline $90 \% \mathrm{O}_{2}+$ rapamycin 7d & $9.67 \pm 1.97^{\mathrm{a}, \mathrm{b}}$ \\
\hline $90 \% \mathrm{O}_{2} 14 \mathrm{~d}$ & $23.83 \pm 3.71^{\mathrm{a}}$ \\
\hline $90 \% \mathrm{O}_{2}+$ rapamycin 14d & $24.0 \pm 3.74^{\mathrm{a}}$ \\
\hline
\end{tabular}

a compared with control group, $\mathrm{p}<0.05$; ${ }^{\mathrm{b}}$ compared with $90 \% \mathrm{O}_{2}$ groups at the same time, $p<0.05$.
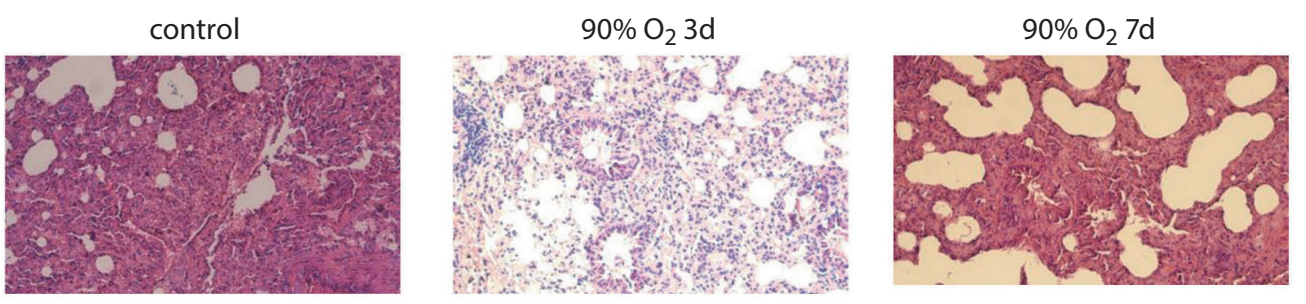

$90 \% \mathrm{O}_{2}+$ rapamycin $3 \mathrm{~d}$

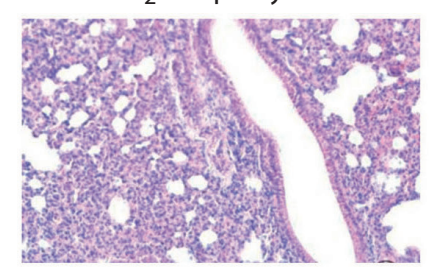

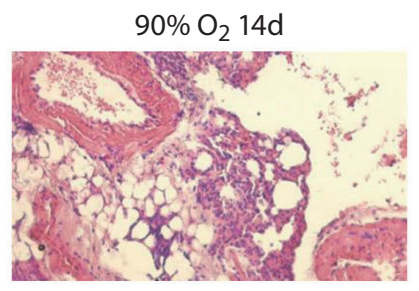

(Fig. 7). Exudation of a few inflammatory cells and red cells was observed in the lungs exposed to $90 \% \mathrm{O}_{2}$ for 3,7 and 14 days, and in a time-dependent manner. After 7 days of exposure to $90 \%$ oxygen, we observed alveolar rupture and fusion, and disordered distribution of cells along the tracheal arteries. After 14 days of exposure to $90 \%$ oxygen, extensive exudation of inflammatory cells and thickening blood vessels and airway walls were observed. The lungs of rats that had received intraperitoneal rapamycin injections and were exposed to $90 \%$ oxygen for 3 days exhibited normal histopathology. Alveolar rupture and fusion, as well as thickening blood vessels and airway walls, were observed in the lungs of rats that had received intraperitoneal injections of rapamycin and were exposed to $90 \%$ oxygen for 7 days. After 14 days of exposure to $90 \%$ oxygen, we observed more severe alveolar rupture and fusion in the lungs of rats that had received intraperitoneal injection of rapamycin.

The pathological scores of lung injury are shown in Table 2. The pathological scores of lung injury in the rats exposed to $90 \%$ oxygen for 3,7 , and 14 days were significantly higher than those of the rats from the control $\left({ }^{a} \mathrm{p}<0.05\right)$. After 3 and 7 days, the pathological lung injury scores of the $90 \% \mathrm{O}_{2}+$ rapamycin group were $(3.50 \pm 0.84)$ and (9.67 \pm 1.97$)$, respectively, which were significantly lower than those of the $90 \% \mathrm{O}_{2}$ group for $3(6.33 \pm 2.34)$ and 7 days $(14.0 \pm 2.45)$, respectively $\left({ }^{\mathrm{b}} \mathrm{p}<0.05\right)$.

\section{Dynamic changes of col I, TGF- $\beta$ and CTGF in lung tissues}

The col I concentration in the lung tissues of rats exposed to $90 \%$ oxygen for 3,7 , and 14 days were $(471.87 \pm 5.72 \mathrm{ng} / \mathrm{mg})$, $(529.72 \pm 6.97 \mathrm{ng} / \mathrm{mg})$, and $(556.44 \pm 8.52 \mathrm{ng} / \mathrm{mg})$, which were significantly higher than those of the air control group $(414.43 \pm 8.97 \mathrm{ng} / \mathrm{mg})\left({ }^{\mathrm{a}} \mathrm{p}<0.05\right)$. The TGF- $\beta$ concentration in the lung tissues of rats exposed to $90 \%$ oxygen for 3,7 and 14 days were $(33.74 \pm 2.84 \mathrm{ng} / \mathrm{mg}),(58.65 \pm 3.10 \mathrm{ng} / \mathrm{mg})$, and

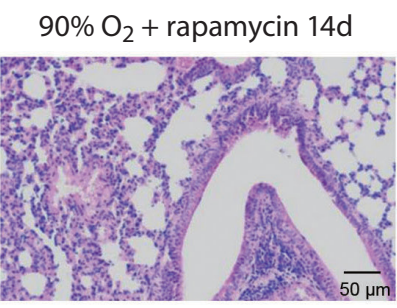

Fig. 7. Histopathological changes of the lung tissues from hyperoxia-induced lung injury rats 
Table 3. The concentrations of TGF- $\beta$, CTGF and col I in the lung tissue determined with ELISA $(n=6)$

\begin{tabular}{|c|c|c|c|}
\hline Group & TGF- $\beta$ [ng/mg] & CTGF [ng/mg] & Col I [ng/mg] \\
\hline Control & $25.50 \pm 1.86$ & $41.23 \pm 1.08$ & $414.43 \pm 8.97$ \\
\hline $90 \% \mathrm{O}_{2} 3 \mathrm{~d}$ & $33.74 \pm 2.84^{a}$ & $50.72 \pm 1.80^{a}$ & $471.87 \pm 5.72^{\mathrm{a}}$ \\
\hline $90 \% \mathrm{O}_{2}+$ rapamycin $3 \mathrm{~d}$ & $25.72 \pm 1.44^{b}$ & $43.45 \pm 1.71^{b}$ & $425.11 \pm 3.50^{b}$ \\
\hline $90 \% \mathrm{O}_{2} 7 \mathrm{~d}$ & $58.65 \pm 3.10^{\mathrm{a}}$ & $68.65 \pm 2.24^{a}$ & $529.72 \pm 6.97^{a}$ \\
\hline $90 \% \mathrm{O}_{2}+$ rapamycin $7 d$ & $34.39 \pm 3.32^{b}$ & $50.92 \pm 2.42^{b}$ & $466.17 \pm 10.60^{b}$ \\
\hline $90 \% \mathrm{O}_{2} 14 \mathrm{~d}$ & $98.81 \pm 1.55^{\mathrm{a}}$ & $94.39 \pm 2.48^{a}$ & $556.44 \pm 8.52^{a}$ \\
\hline $90 \% \mathrm{O}_{2}+$ apamycin $14 d$ & $54.31 \pm 4.25^{b}$ & $63.64 \pm 2.78^{b}$ & $511.72 \pm 13.72^{b}$ \\
\hline
\end{tabular}

${ }^{a}$ compared with control group, $\mathrm{p}<0.05 ;{ }^{b}$ compared with $90 \% \mathrm{O}_{2}$ groups at the same time, $\mathrm{p}<0.05$; col I - collagen I.

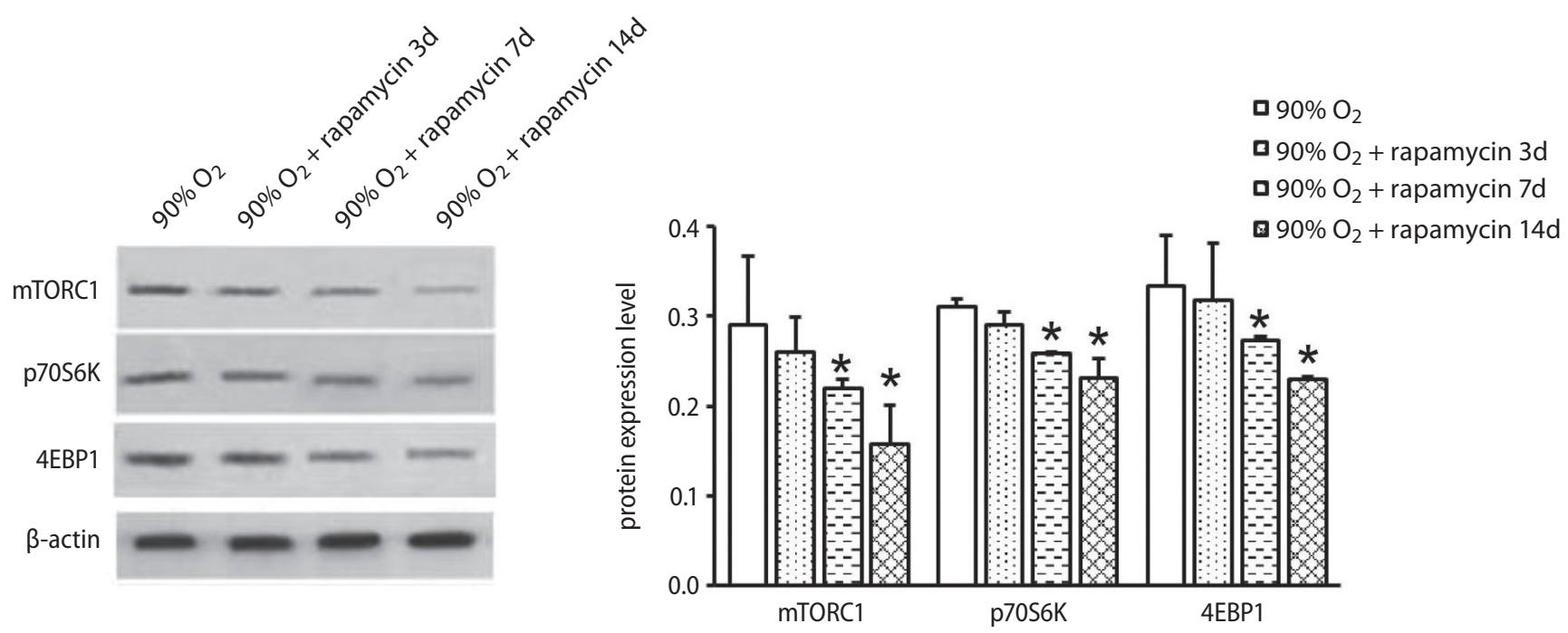

Fig. 8. The protein expression of mTORC1, p70S6K and 4EBP1 in the lung tissues of rats of all experimental groups were detected with western blot

$* \mathrm{p}<0.05$ vs $90 \% \mathrm{O}_{2}$ group.

(98.81 $\pm 1.55 \mathrm{ng} / \mathrm{mg})$, which were significantly higher than those of the control group $(25.50 \pm 1.86 \mathrm{ng} / \mathrm{mg})\left({ }^{\mathrm{a}} \mathrm{p}<0.05\right)$. The CTGF concentration in the lung tissues of rats exposed to $90 \%$ oxygen for 3,7 , and 14 days were $(50.72 \pm 1.80$ $\mathrm{ng} / \mathrm{mg}),(68.65 \pm 2.24 \mathrm{ng} / \mathrm{mg})$, and $(94.39 \pm 2.48 \mathrm{ng} / \mathrm{mg})$, which were significantly higher than those of the control group $(41.23 \pm 1.08 \mathrm{ng} / \mathrm{mg})\left({ }^{\mathrm{a}} \mathrm{p}<0.05\right)$. These results suggest that the production of pulmonary fibrosis factors was induced by $90 \%$ oxygen. Compared with the $90 \%$ oxygen group, rapamycin significantly reduced the concentrations of col I, TGF- $\beta 1$, and CTGF in the lung tissues of rats exposed to $90 \%$ oxygen for 3,7 , and 14 days $\left({ }^{b} \mathrm{p}<0.05\right)$ (Table 3).

\section{Rapamycin inhibits the mTOR pathway in the lung tissue of rats}

The above results indicated that rapamycin attenuates acute lung injury induced by $90 \%$ oxygen. The objective of western blot was to determine whether the mTOR pathway was involved in the repair of lung injury. As shown in Fig. 8, the expression levels of mTORC1, p70S6K, and $4 \mathrm{EBP} 1$ in the lung tissue of rats in the $90 \% \mathrm{O}_{2}+$ rapamycin group were significantly decreased compared with control animal at day 7 and 14 (*p $<0.05)$, which suggested that the application of rapamycin could inhibit the activation of mTOR signaling pathway and inhibit the expression of downstream proteins p70S6K and 4EBP1.

\section{Discussion}

In the present study, we found that exposure to oxygen concentrations of $40 \%, 60 \%$, and $90 \%$ all promoted the apoptosis of L929 cells in a time and concentrationdependent manner. Application of $10 \mathrm{nM}$ rapamycin or transfected with mTOR siRNA could inhibit the activation of mTOR signaling pathway and promote the apoptosis of L929 cells exposed to $90 \% \mathrm{O}_{2}$, and down-regulate the expression of the downstream proteins 4EBP1, and p70S6K. Exposure to $90 \%$ oxygen increased the production of col I, col III, and FN in ECM of L929 cells; however, inhibition of the mTOR signaling pathway decreased the production of col I, III and FN, which could reduce hyperoxia-induced pulmonary fibrosis. In lung tissues of hyperoxia-induced lung injury rats, we found that rapamycin inhibited 
the activation of the mTOR pathway, which protected the lung from the oxidative injury and fibrosis induced by high concentration of oxygen.

Lung fibroblasts play an important role in the repair of lung injury. Yang et al. found that high oxygen concentrations inhibited the proliferation of fibroblasts isolated from embryonic lungs. ${ }^{25}$ The mTOR signaling pathway is essential for cell proliferation, survival, and migration by regulating the transcription and translation of proteins. ${ }^{26}$ Rapamycin is a specific inhibitor of the mTOR pathway. ${ }^{27}$ Sun et al. found that $0.01-10 \mathrm{nM}$ rapamycin could inhibit the proliferation of lung cancer cells; however, only $>1 \mathrm{nM}$ rapamycin quickly inhibited the phosphorylation of downstream proteins and the growth of lung cancer cells. ${ }^{28}$ In the present study, mTOR siRNA down-regulated the expression of mTORC1, 4EBP1, and p70S6K, suggesting that mTOR can specifically regulate the expression of 4EBP1 and p70S6K. The extracellular matrix is synthesized and secreted by animal cells to form a network structure between cells, which consists of protein and polysaccharide. ${ }^{29}$ In the present study, we found that blocking the mTOR signaling pathway inhibited collagen deposition in L929 cells, which prevented the lung fibrosis caused by oxidative injury. Collagen deposition in the lung is one of the most important causes and major characteristics of pulmonary fibrosis. ${ }^{30}$ In the pathology of pulmonary fibrosis, apoptosis-related proteins, such as Bcl-2, P53, and caspase-3, as well as other cytokines, interplay to promote the proliferation of lung fibroblasts, which replace alveolar type II epithelial cells (AT II), subsequently causing pulmonary fibrosis. ${ }^{31-33}$ TGF- $\beta$ and CTGF could activate the PI3K/Akt/mTOR signaling pathway, promoting the proliferation, collagen synthesis, and antiapoptotic ability of lung fibroblasts. TGF- $\beta$, which is a key component in a number of cytokine networks, is currently recognized to be one of the most powerful factors causing fibrosis. ${ }^{34}$ Lee and Kim reported that CTGF was closely associated with TGF- $\beta$ in pulmonary fibrosis. ${ }^{35}$ Connective tissue growth factor is a newly identified cytokine closely involved in pulmonary fibrosis and is widely distributed in human tissues and organs; it plays important roles in cell adhesion, fibroblast proliferation, and ECM synthesis. ${ }^{36}$ In the present study, we observed increased expression of CTGF and TGF- $\beta$, which was induced by $90 \%$ oxygen. Additionally, we found that blocking the mTOR pathway could down-regulate the expression of CTGF and TGF- $\beta$, which suggests that rapamycin could decrease the expression CTGF and TGF- $\beta$ through inhibiting the activation of mTOR signaling pathway. In other words, the mTOR pathway is involved in lung fibrosis by regulating the expression of CTGF and TGF- $\beta$.

The mammalian target of rapamycin is widely found in mammals in 2 complex forms: mTORC1 and mTORC2. As the target protein of rapamycin, mTORC1 is sensitive to rapamycin; however, mTORC2 is not. ${ }^{27}$ The mammalian target of rapamycin complex 1 regulates cell growth, proliferation, and metabolism by phosphorylating 2 major downstream proteins, S6K1 and eukaryotic initiation factor $4 \mathrm{E}-\mathrm{BP} 1$. In the present study, we found that $90 \% \mathrm{O}_{2}$ induced lung injury in premature rats in a time-dependent manner. We also observed increased expression of fibrosis-related proteins, including TGF- $\beta$, CTGF, col II and col III, in the lung tissue of rats, also in a time-dependent manner. These results suggest that lung injury induced by a high concentration of oxygen is consistent with lung fibrosis. High concentrations of oxygen induced changes in the expression of mTORC1, p70S6K, and 4EBP1, which are key components of the mTOR pathway, suggesting that the mTOR pathway is activated by high concentrations of inhaled oxygen. It has been reported that the mTOR pathway is activated in lipopolysaccharide (LPS)-induced acute lung injury (ALI) in mice and rapamycin reduced the expression of inflammatory factors in bronchoalveolar lavage fluid (BLF). ${ }^{37}$ Lorne et al. reported that the phosphorylation of rpS6 and 4EBP1, 2 effector proteins of the mTOR signaling pathway, induced the over-production of inflammatory cytokines by neutrophils in ALI, which could be inhibited by rapamycin. ${ }^{38}$ It has been reported that rapamycin administration causes a significant reduction of p70S6K phosphorylation, increased autophagy, decreases neuronal cells apoptosis and significantly reduces brain damage in neonatal rats, which testifies to the neuroprotective effect of rapamycin in neonatal hypoxia-ischemia. ${ }^{39}$ Furthermore, it was found that the inhibition of the mTOR signaling pathway by rapamycin prevented the development and progression of lung fibrosis in a rat pulmonary fibrosis model that was induced by TGF- $\alpha{ }^{21}$ Tulek et al. also found that rapamycin could inhibit the progress of lung fibrosis in the early stage of bleomycin-induced pulmonary fibrosis in rats. ${ }^{40}$ Therefore, we speculate that the mTOR signaling pathway plays an important role in the repair of hyperoxia-induced lung injury by regulating the expression of TGF- $\beta$ and CTGF. Rapamycin can effectively inhibit the activation of the mTOR signaling pathway and downregulate downstream target proteins P70S6K and 4EBP1, and reduce the production of TGF- $\beta$ and CTGF, inhibiting the development of pulmonary fibrosis induced by high concentration oxygen exposure.

\section{Conclusions}

Our results suggest that rapamycin prevents the progression of lung fibrosis induced by high concentrations of oxygen by inhibiting the mTOR signaling pathway, including suppressing the expression of p70S6K, 4EBP1, TGF- $\beta$, and CTGF. Therefore, rapamycin may be useful for the treatment of hyperoxia-induced ALI. Our results help elucidate the molecular mechanism underlying hyperoxiainduced lung injury and may contribute to the identification of novel targets for its treatment. 


\section{References}

1. Mirza H, Ziegler J, Ford S, Padbury J, Tucker R, Laptook A. Pulmonary hypertension in preterm infants: Prevalence and association with bronchopulmonary dysplasia. J Pediatr. 2014;165(5):909-914.

2. Zhou W, Zhang X, Feng Z. Risk factors, incidence and severity of bronchopulmonary dysplasia (BPD) in the world's largest neonatal intensive care units (NICUs) in China. Klin Padiatr. 2012;224(7):2095-2099.

3. Greenspan JS, Goldsmith JP. Oxygen therapy in preterm infants: Hitting the target. Pediatrics. 2006;118(4):1740-1741.

4. Garat C, Jayr C, Eddahibi S, Laffon M, Meignan M, Adnot S. Effects of inhaled nitric oxide or inhibition of endogenous nitric oxide formation on hyperoxic lung injury. Am J Respir Crit Care Med. 1997;155(6): 1957-1964.

5. Dubaybo BA, Rubeiz GJ, Fligiel SE. Dynamic changes in the functional characteristics of the interstitial fibroblast during lung repair. Exp Lung Res. 1992;18(4):461-477.

6. Rocco PR, Negri EM, Kurtz PM, et al. Lung tissue mechanics and extracellular matrix remodeling in acute lung injury. Am J Respir Crit Care Med. 2001;164(6):1067-1071.

7. Xia H, Diebold D, Nho R, et al. Pathological integrin signaling enhances proliferation of primary lung fibroblasts from patients with idiopathic pulmonary fibrosis. J Exp Med. 2008;205(7):1659-1672.

8. Uhal BD, Joshi I, True AL, et al. Fibroblasts isolated after fibrotic lung injury induce apoptosis of alveolar epithelial cells in vitro. Am JPhysiol. 1995;269(1):819-828.

9. Hay N, Sonenberg N. Upstream and downstream of mTOR. Genes Dev. 2004;18(16):1926-1945.

10. Zoncu R, Efeyan A, Sabatini DM. mTOR: From growth signal integration to cancer, diabetes and ageing. Nat Rev Mol Cell Biol. 2010;12(1): 21-35.

11. Thomas GV, Tran C, Mellinghoff IK, et al. Hypoxia-inducible factor determines sensitivity to inhibitors of mTOR in kidney cancer. Nat Med. 2006;12(1):122-127.

12. Hentges KE, Sirry B, Gingeras AC, et al. FRAP/mTOR is required for proliferation and patterning during embryonic development in the mouse. Proc Natl Acad Sci USA. 2001;98(24):13796-13801.

13. Hwang M, Perez CA, Moretti L, Lu B. The mTOR signaling network: Insights from its role during embryonic development. Curr Med Chem. 2008;15(12):1192-1208.

14. Land SC, Scott CL, Walker D. mTOR signalling, embryogenesis and the control of lung development. Semin Cell Dev Biol. 2014;36:68-78.

15. Costes F, Gosker H, Feasson L, et al. Impaired exercise training-induced muscle fiber hypertrophy and Akt/mTOR pathway activation in hypoxemic patients with COPD. J App/ Physiol. 2015;118(8):1040-1049.

16. Makam M, Diaz D, Laval J, et al. Activation of critical, host-induced, metabolic and stress pathways marks neutrophil entry into cystic fibrosis lungs. Proc Natl Acad Sci USA. 2009;106(14):5779-5783.

17. Gui YS, Wang $L$, Tian $X$, et al. mTOR overactivation and compromised autophagy in the pathogenesis of pulmonary fibrosis. PLos One. 2015; 10(9):e0138625. doi: 10.1371/journal.pone.0138625

18. Gäbele E, Reif S, Tsukada S, et al. The role of p70S6K in hepatic stellate cell collagen gene expression and cell proliferation. J Biol Chem. 2005;280(14):13374-13382.

19. Park JS, Park HJ, Park YS, et al. Clinical significance of mTOR, ZEB1, ROCK1 expression in lung tissues of pulmonary fibrosis patients. $B M C$ Pulm Med. 2014;14:168.

20. Chung EJ,Sowers AL, Thetford A, Mckay-Corkum G, Mitchell JB, Citrin DE. mTOR inhibition with rapamycin mitigates radiation-induced pulmonary fibrosis in a murine model. Int J Radiat Oncol Biol Phys. 2016; 96(4):857-866.

21. Korfhagen TR, Le CT, Davidson CR, et al. Rapamycin prevents transforming growth factor-alpha-induced pulmonary fibrosis. Am J Respir Cell Mol Biol. 2009;41(5):562-572.
22. Zhang L, Zhao S, Yuan L, et al. Knockdown of placental growth factor (PLGF) mitigates hyperoxia-induced acute lung injury in neonatal rats: Suppressive effects on NFKB signaling pathway. Int Immunopharmacol. 2016;38:167-174.

23. Sun X, Threadgill D, Jobin C. Campylobacter jejuni induces colitis through activation of mammalian target of rapamycin signaling. Gastroenterology. 2012;142(1):86-95.

24. Murakami K, Mcguire R, Cox RA, et al. Heparin nebulization attenuates acute lung injury with sepsis after smoke inhalation in sheep. Shock. 2002;18(3):236-241.

25. Yang $P, H e X Q$, Peng $L$, et al. The role of oxidative stress in hormesis induced by sodium arsenite in human embryo lung fibroblast (HELF) cellular proliferation model. J Toxicol Environ Health A. 2007;70(11): 976-983.

26. Sarbassov DD, Ali SM, Sabatini DM. Growing roles for the mTOR pathway. Curr Opin Cell Biol. 2005;17(6):596-603. doi: 10.1371/journal.pbio.1000038

27. Feldman ME, Apsel B, Uotila A, et al. Active-site inhibitors of mTOR target rapamycin-resistant outputs of mTORC1 and mTORC2. PLoS Biol. 2009;7(2):e38.

28. Sun SY, Rosenberg LM, Wang X, et al. Activation of Akt and elF4E survival pathways by rapamycin-mediated mammalian target of rapamycin inhibition. Cancer Res. 2005;65(16):7052-7058.

29. Pizzo AM, Kokini K, Vaughn LC, Waisner BZ, Voytik-Harbin SL. Extracellular matrix (ECM) microstructural composition regulates local cell-ECM biomechanics and fundamental fibroblast behavior: A multidimensional perspective. J Appl Physiol. 2005;98(5):1909-1921.

30. Mercer RR, Scabilloni J, Wang L, et al. Alteration of deposition pattern and pulmonary response as a result of improved dispersion of aspirated single-walled carbon nanotubes in a mouse model. Am J Physiol Lung Cell Mol Physiol. 2008;294(1):L87-97.

31. Wu SH, Wu XH, Lu C, Dong L, Chen ZQ. Lipoxin A4 inhibits proliferation of human lung fibroblasts induced by connective tissue growth factor. Am J Respir Cell Mol Biol. 2006;34(1):65-72.

32. Choi JE, Lee SS, Sunde DA, et al. Insulin-like growth factor-I receptor blockade improves outcome in mouse model of lung injury. Am $J$ Respir Crit Care Med. 2009;179(3):212-219.

33. Vittal R, Horowitz JC, Moore BB, et al. Modulation of prosurvival signaling in fibroblasts by a protein kinase inhibitor protects against fibrotic tissue injury. Am J Pathol. 2005;166(2):367-375.

34. Moussad EE, Brigstock DR. Connective tissue growth factor: What's in a name? Mol Genet Metab. 2000;71(1-2):276-292.

35. Lee HS, Kim CK. Effect of recombinant IL-10 on cultured fetal rat alveolar type II cells exposed to 65\%-hyperoxia. Respir Res. 2011;12:68. doi: 10.1186/1465-9921-12-68

36. Chen S, Rong M, Platteau A, et al. CTGF disrupts alveolarization and induces pulmonary hypertension in neonatal mice: Implication in the pathogenesis of severe bronchopulmonary dysplasia. Am J Physiol Lung Cell Mol Physiol. 2011;300(3):330-340.

37. Wang L, Gui YS, Tian X, et al. Inactivation of mammalian target of rapamycin (mTOR) by rapamycin in a murine model of lipopolysaccharide-induced acute lung injury. Chin Med J (Engl). 2011;124(19): 3112-3117.

38. Lorne E, Zhao X, Zmijewski JW, et al. Participation of mammalian target of rapamycin complex 1 in toll-like receptor 2- and 4-induced neutrophil activation and acute lung injury. Am J Respir Cell Mol Bio. 2009;41(2):237-245.

39. Carloni S, Girelli S, Scopa C, Buonocore G, Longini M, Balduini W. Activation of autophagy and Akt/CREB signaling play an equivalent role in the neuroprotective effect of rapamycin in neonatal hypoxia-ischemia. Autophagy. 2010;6(3):366-377.

40. Tulek B, Kiyan E, Toy H, Kiyici A, Narin C, Suerdem M. Anti-inflammatory and anti-fibrotic effects of sirolimus on bleomycin-induced pulmonary fibrosis in rats. Clin Invest Med. 2011;34(6):E341. 